\title{
Effect of Real Exchange Rate Volatility on Agricultural Products Export in Nigeria
}

\author{
Friday Otse Alegwu, Goodness C. Aye, Benjamin Chijioke Asogwa \\ Department of Agricultural Economics, University of Agriculture, Makurdi, Nigeria
}

\begin{abstract}
This study examines the effects of real exchange rate volatility on agricultural products export in Nigeria using annual time series data from1970 to 2013. The long run, short run and causal effects of real exchange rate volatility on agricultural products export were evaluated. VECM was used to evaluate the effects of real exchange rate volatility on agricultural products export. The Augmented Dickey-Fuller (ADF) and Philip Perron (PP) unit root tests confirm that all variables were stationary in their first difference. Further investigation based on the Johansen co-integration tests indicates that one co-integration exists between exchange rate volatility and each of the agricultural products export while controlling for other variables. Exchange rate volatility has negative long run effect on all agricultural exports studied with the effect being strongest for coffee followed by rubber. The results based on Vector Error Correction Model (VECM) show evidence of negative but insignificant short run effects of real exchange rate volatility on agricultural products export. From the Granger causality test, there exists bidirectional causality between cocoa and real exchange rate volatility. The implications of these findings are drawn.
\end{abstract}

\section{Keywords}

Real exchange rate, volatility, overvaluation, undervaluation, agricultural products, export, effect.

Alegwu, F. O., Aye, G. C. and Asogwa, B. C. (2018) "Effect of Real Exchange Rate Volatility on Agricultural Products Export in Nigeria", AGRIS on-line Papers in Economics and Informatics, Vol. 10, No. 3, pp. 3-15. ISSN 1804-1930. DOI 10.7160/aol.2018.100301.

\section{Introduction}

Agricultural commodity trade has played a prominent role in Africa's economic development. As suppliers of raw materials to western economies, African countries have continued to produce primary crops for export. Thus the agricultural exports sector is still the most important single activity for Africans (Amoro and Shen, 2013). Africa's agricultural commodity exports may be categorized into traditional and non - traditional. The prominent traditional export commodities include cocoa, palm oil, palm kernel, rubber, cotton, groundnut, kola nut among others. The non - traditional export commodities include pineapple, cashew, eggs, processed fruits, alcoholic beverages to mention but a few which have emerged as the most demanded products in the international markets (Nwachukwu, 2014).

Nigeria has a long history of thriving exports of top quality produce like cocoa, cotton, gum Arabic, sesame seed, rubber, ginger, pineapples, coffee and a host of others. Export markets for these products exist in United States of America (USA), European Union, Gulf States, Japan, Singapore, China to mention but a few countries. Nigeria appears to have an added advantage over major agricultural producers and exporters in the Eastern and Southern Africa in terms of fertile land, proximity to traditional and terminal markets in Europe by air or by sea (Sasore, 2004).

In view of the poor performance of the agricultural sector in recent years and the impact of most of the economic reform programmes on agricultural supply in Nigeria, most commentary on the impact of adjustment on agriculture points to the fact that the reforms are showing the desired outcomes, but others think otherwise. Price reform is a necessary but insufficient condition for increased output (Abiodun and Salau, 2010). While supply response for food or export crops can be significant, aggregate supply response may be comparatively low, suggesting that at least some increased output might have occurred through switching of resources between them, with changing price incentives. 
The volatile nature of exchange rates has become a major problem in estimating the scope and nature of trading behaviours and trade volumes extant between exporting and importing countries (Orden, 2002). The unpredictable nature of the exchange rate always leads risk-averse traders to reduce their trading activities with foreign countries and it is these traders' collective aversion which ultimately impacts the total trade of the nation in reducing exports and import volumes. As a result of reduced trading activities, the trade deficit becomes increasingly negative and nominal prices for agricultural and other primary commodities increase as a consequence of a flexible dollar.

So far there are a considerable numbers of studies on exchange rate volatility and aggregate trade. There are also sectoral studies and few studies specifically on agricultural trade and exchange rate volatility such as De Vita and Abbot, 2004; Awokuse and Yuan, 2006; Wang and Barrett 2007; Cho et al. 2002; Kandilov 2008 and Foragasi, 2011. However, there are no studies to the best of my knowledge on agricultural products export and real exchange rate volatility. In other words the current study contributes by disaggregating the agricultural export into various products as to ascertain which one(s) are actually driven by exchange rate volatility. On sectoral level analysis for example De Vita and Abbott (2004), observe that short-term volatility in exchange rate does not affect United Kingdom (UK) exports to the European Union (EU) both at the aggregate and sectoral levels. However, there are significant negative effects of long-term volatility on UK exports to the EU. The negative link is attributed to the difficulty to hedge against long-run fluctuations. Awokuse and Yuan (2006) examine the relationship between exchange rate volatility and US poultry exports using a panel data for 49 importing nations over two sub-periods: 1976-1985 and 1986-2000. Results based on fixed-effects model specification and three alternative measures of exchange rate volatility show that the choice of volatility measure matters and there is a positive relationship between exchange rate uncertainty and poultry exports.

Wang and Barrett (2007) analyzed the effect of exchange rate volatility on international trade flows by studying the case of Taiwan's exports to the United States from 1989-1999. They found that real exchange rate risk has insignificant effects in most sectors, although agricultural trade volumes appear highly responsive to real exchange rate volatility and the effect is negative. Cho et al. (2002) used panel data on bilateral trade and exchange rate volatility for the set of G-10 countries they investigate the effects of long-run real exchange rate volatility on agricultural trade in comparison to other sectors. They conclude that real exchange rate volatility has a significant negative effect on agricultural trade. The estimated impact on agricultural trade is much larger than the estimated impact on trade in other sectors and on aggregate trade. Kandilov (2008) using different index of uncertainty and data over the period 1974 to 1997 replicate these results. Specifically he found that exchange rate volatility had a negative impact on trade flows and the impact was larger in agricultural trade as compared to other sectors. Furthermore, he found a larger impact of exchange rate volatility on exports from developing countries than on exports from developed countries.

In his study of Hungarian agricultural exports to its export destination, Foragasi (2011) found a positive effect of nominal exchange rate volatility on agricultural trade between Hungary and 81 trade partners around the world for 9 years (1999-2008). He used the gravity model and panel data procedure in his analysis. He further concluded that because of the positive effect that exchange rate volatility has on agricultural trade flows, Hungarian agricfood entrepreneurs are not interested in joining the Euro-zone.

From the foregoing, it is noted that although there are a handful of studies on the relationship between exchange rate volatility and agricultural trade, none of these studies considered the individual agricultural products. Therefore, the main objective of this study is to examine the effect of real exchange rate volatility on agricultural products export in Nigeria. The specific objectives are to: examine the long run effect of real exchange rate volatility on agricultural products export in the study area; determine the short run effect of real exchange rate volatility on agricultural products export in Nigeria; analyze the causal relationship between real exchange rate volatility and agricultural products export in the study area.

The rest of this study is organized as follows: chapter 2 describes the materials used for investigation and the methodology, while chapter 3 presents the empirical results and discussion, and finally chapter 4 concludes the paper.

\section{Materials and methods}

Secondary data were employed for this study. The data are annual time series data covering 1970-2013. The data on agricultural products export were sourced from Food and Agriculture Organization (FAO)-STAT website, data on real 
exchange rate, inflation rate and interest rate were sourced from Central Bank of Nigeria (CBN) Statistical Bulletin/Annual Report and World Bank database, data on trade openness index were also sourced from World Bank database. Exchange rate volatility is unobservable and hence was constructed from a $\operatorname{GARCH}(1,1)$ model. All variables were transformed to their natural logarithm.

Both descriptive statistics and inferential statistics were used for analyzing the data. Descriptive statistics such as mean, standard deviation, percentage and kurtosis and skewness as well as graphs were employed. Further, Augmented Dickey-Fuller (ADF) and Phillips-Perron (PP) tests were also used to ascertain the time series properties (stationarity) of all the variables so as to avoid spurious regression. Other models used include Johansen's Maximum Likelihood Co-integration test to determine the long run relationship between real exchange rate volatility and agricultural products export. Vector Error Correction Model (VECM)was used for analyzing the short run effect of exchange rate volatility due to the existence of co-integration and the Granger Causality test was used to determine the causal links between the variables.

\section{Vector error correction model}

To estimate the short-run relationship between the variables, the vector error correction equation is specified for the case of existence of co-integration (long-run) relationship between for example cocoa export and real exchange rate volatility:

$$
\begin{aligned}
& \Delta \ln E X \operatorname{COC}_{t}=\alpha_{1}+\sum_{i=1}^{p} \beta_{i} \Delta \ln E X \operatorname{COC}_{t-i}+\sum_{i=1}^{p} \gamma_{i} \Delta \ln R E R V_{t-i} \\
& +\sum_{i=1}^{p} \theta_{i} \Delta \operatorname{lnINF_{t-i}}+\sum_{i=1}^{p} \delta_{i} \Delta \operatorname{lnINR}_{t-i}+\sum_{i=1}^{p} \vartheta_{i} \Delta \operatorname{lnTOP_{t-i}} \\
& +\varphi_{1} \mu_{\mathrm{t}-\mathrm{i}}+\varepsilon_{1 t} \\
& \Delta \ln R E R V_{t}=\alpha_{2}+\sum_{i=1}^{p} \pi_{i} \Delta \ln R E R V_{t-i}+\sum_{i=1}^{p} \rho_{i} \Delta \ln E X \operatorname{COC}_{t-i}
\end{aligned}
$$

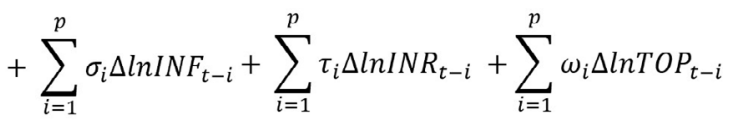

$$
\begin{aligned}
& +\varphi_{2} \mu_{\mathrm{t}-\mathrm{i}}+\varepsilon_{2 t}
\end{aligned}
$$

where: $E X C O C=$ Cocoa export, $R E R V=$ Real exchange rate volatility, $I N F=$ Inflation rate, $I N R=$ Interest rate, $T O P=$ Trade openness, $l n=$ Natural Logarithm, $\Delta=$ Difference operator, $\mu_{t-i}=$ Error correction term, $\varphi_{i}=$ Speed of adjustment, $\varepsilon_{1 t}$ and $\varepsilon_{2 t}=$ Error or random term.

It is important to note that the estimation was carried out for each agricultural product export. Hence EXCOC was replaced with EXRUB (rubber export) or EXCOT (cotton export) or EXCOF (coffee export) depending on the one being analyzed. The specifications for the control variables are eliminated for brevity. The study used the VECM estimates and associated impulse response functions and variance decompositions to examine the relationships.

\section{Granger causality test}

The bivariate Granger causality test was used to explore the causality between real exchange rate volatility and the agricultural products export. An appropriate formulation or specifications of the co-integrated error-correction Granger causality between cocoa export (EXCOC) and real exchange rate volatility (RERV) were specified as:

$$
\begin{aligned}
& \Delta \ln (E X C O C)_{t}=\alpha_{1}+\sum_{i=1}^{n} \beta_{i} \Delta \ln (E X C O C)_{t-i}+\sum_{i=1}^{m} \delta_{j} \Delta \ln (R E R V)_{t-j} \\
& +r_{1}\left(E C_{1}\right)_{t-1}+\varepsilon_{t} \\
& \Delta \ln (R E R V)_{t}=\alpha_{2}+\sum_{i=1}^{n} c_{i} \Delta \ln (R E R V)_{t-i}+\sum_{i=1}^{m} g_{j} \Delta \ln (E X C O C)_{t-j} \\
& +r_{2}\left(E C_{2}\right)_{t-1}+\mu_{t}
\end{aligned}
$$

where: $\Delta=$ first-difference operator, $E X C O C=$ Cocoa export, $R E R V=$ exchange rate volatility, ln $=$ natural logarithm transformation; $\alpha_{1}$ and $\alpha_{2}=$ intercept $, \beta_{i}, \delta_{i}, g_{\mathrm{i}}$, and $c_{i}=$ Coefficient, $\varepsilon_{t}$ and $\mu_{t}=$ error or random terms, $n$ and $m=$ numbers of lag lengths chosen by the Akaike Information Criterion (AIC). After estimating the VAR, we examined the lag structure. This process yields results from several lag length selection criteria such as sequential modified LR test statistic, Final prediction error (FPE), Akaike information criterion (AIC), Schwarz information criterion (SC) and Hannan-Quinn information criterion (HQ). The final selected lag order was then based on AIC though SIC produced relatively similar results as AIC. These two are usually more parsimonious and choose the well specified model asymptotically (Ivanov and Kilian, 2005). (EC $)_{t-1}$ and $\left(E C_{2}\right)_{t-1}$ $=$ error correction terms which represent the lag residuals from the co-integration equations. If $\delta_{j}$ is significant but $g_{j}$ is not, then there is a unidirectional causality from real exchange rate volatility to cocoa export. Conversely, if $g_{j}$ is significant and $\delta_{j}$ is not, then there is a unidirectional causality from cocoa export to real exchange rate volatility. If both $\delta_{j}$ and $g_{j}$ are significant, there is a bidirectional causality meaning real exchange rate volatility Granger causes cocoa export and vice versa. If both coefficients are not significant, there is no causality 
running from any of the variables to the other. Again the Granger causality was examined for each pair of agricultural products export and real exchange rate volatility.

\section{Results and discussion}

\section{Descriptive Statistics}

The log plots of the respective time series are also presented in Figure 1. In general, the series do not tend to revert to their equilibrium level which may be an indication of unit root process. However, formal unit root will be applied in the next section.

\section{Unit root test}

Table 1 presents the results of the unit root tests based on the Augmented Dickey-Fuller (ADF) and Phillip-Perron (PP).The tests were applied to each variable over the period of 1970-2013 both in level and at their first difference. The test statistics are compared against the Mackinnon (1991) critical values for the rejection or otherwise of the null hypothesis of unit root. Table 1 confirm that all variables: Cocoa export (EXCOC), Coffee export (EXCOF), Cotton export(EXCOT), Rubber export (EXRUB), Inflation rate (INF), Interest rate (INR), Real exchange rate volatility (RERV) and Trade openness (TOP) were non-stationary in their level form as evidenced by large p-values. This implies that one cannot reject the null hypothesis of unit root, that is, non-stationarity.
After differencing, the variables became stationary as the null hypothesis of unit root is rejected for all variables. This indicates that the variables are integrated of order 1, I(1) and any attempt to specify the dynamic function of the variable in the level of the series will be inappropriate and may lead to problems of spurious regression in line with Mesike et al (2010). The econometric results of the model using the level of these series will not be ideal for policy making (Yusuf and Falusi, 1999) and such results cannot be used for prediction in the long-run. Johansen co-integration test therefore becomes appropriate for assessing the long- run relationship among variables.

Long run analysis between real exchange rate volatility and agricultural products export

The Johansen co-integration test was employed to test for the existence of long run relationship between real exchange rate volatility and the various agricultural products export. The co-integration test results are presented in table 2 for both the trace and max-eigen statistics. The co-integration test results for real exchange rate volatility and cocoa export are presented in the first panel of table 2 . The results indicate that co-integration exists among the variables. This is indicated by the MaxEigen statistics of 42.540 which is greater than the critical value of 33.877 as well as the trace statistic of 88.944 which is greater than the critical

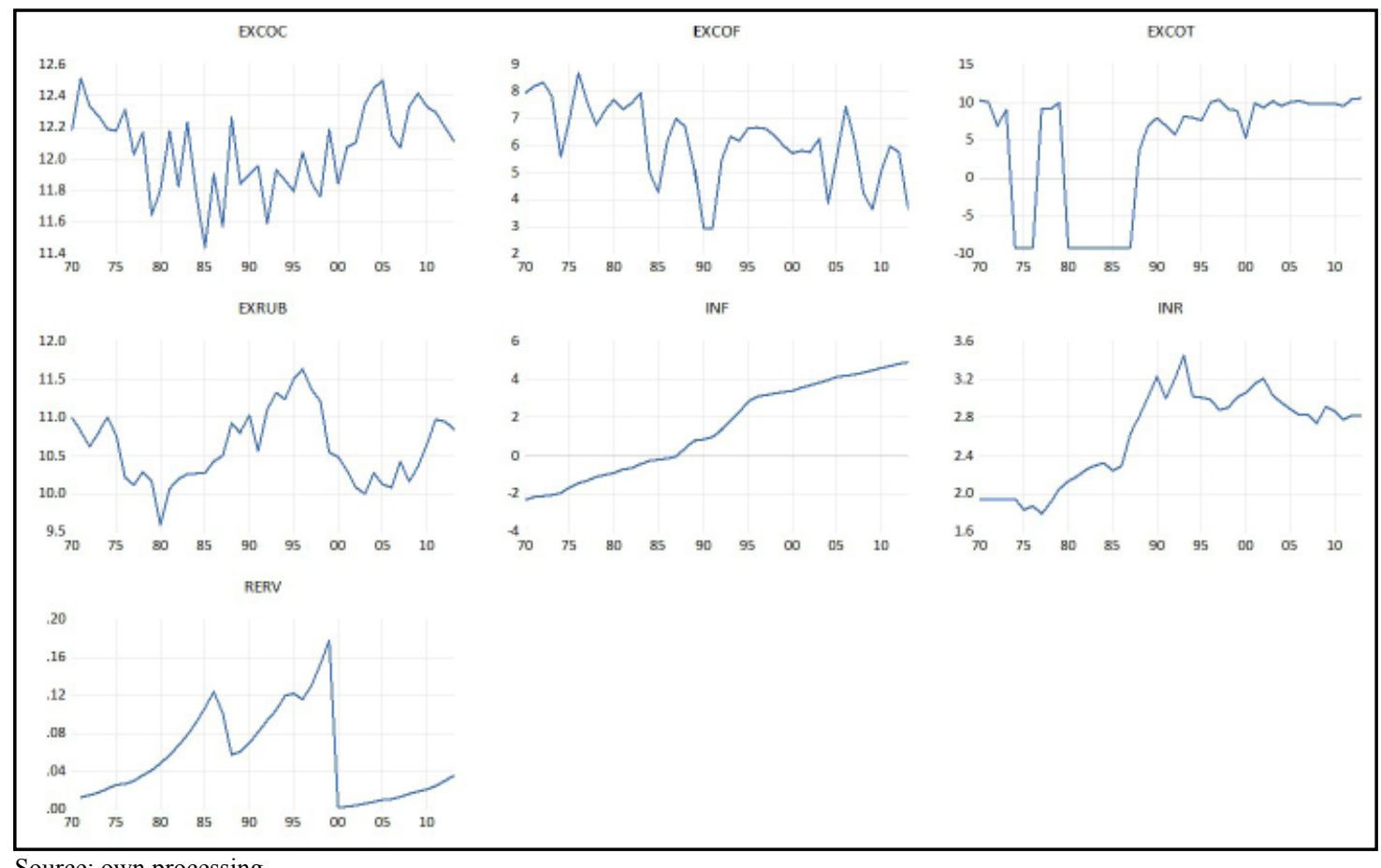

Source: own processing 


\begin{tabular}{lcccc}
\hline Variable & \multicolumn{2}{c}{ ADF } & PP \\
\hline EXCOC & Level & First difference & Level & First difference \\
& -1.161 & $-6.147^{* * *}$ & -0.112 & $-14.699^{* * *}$ \\
EXCOF & -0.681 & 0.000 & -0.639 & 0.000 \\
& -2.318 & $-8.003^{* * *}$ & -1.273 & $-6.741^{* * *}$ \\
EXCOT & -0.171 & 0.000 & -0.184 & 0.000 \\
& -2.324 & $-6.522^{* * *}$ & -2.380 & $-9.343^{* * *}$ \\
EXRUB & -0.169 & 0.000 & -0.153 & 0.000 \\
& -2.048 & $-6.607^{* * *}$ & -2.182 & $-6.610^{* * *}$ \\
INF & -0.266 & 0.000 & -0.216 & 0.000 \\
& -0.725 & $-3.243^{* *}$ & -0.576 & $-3.075^{* *}$ \\
INR & -0.829 & -0.024 & -0.865 & -0.036 \\
RERV & -1.405 & $-6.207^{* * *}$ & -1.434 & $-6.222^{* * *}$ \\
TOP & -0.571 & 0.000 & -0.557 & 0.000 \\
& -2.202 & $-6.533^{* * *}$ & -2.240 & $-6.623^{* * *}$
\end{tabular}

Note: $* *$ and $* * *$ denote rejection of the null hypothesis at $5 \%$ and $1 \%$ significance level respectively based on the Mackinnon critical values. P-values of corresponding test statistic are given in parenthesis.

Source: author's computation from E-views (2016)

Table 1: Unit root test results.

\begin{tabular}{|c|c|c|c|c|c|c|c|}
\hline Но & $\mathrm{H} 1$ & Statistic & $5 \% \mathrm{CV}$ & Ho & $\mathrm{H} 1$ & Statistic & $5 \% \mathrm{CV}$ \\
\hline$r=0$ & $r \geq 1$ & $88.944 * *$ & 69.819 & $\mathrm{r}=0$ & $\mathrm{r}=1$ & $42.540 * *$ & 33.877 \\
\hline $\mathrm{r} \leq 1$ & $r \geq 2$ & 46.404 & 47.856 & $\mathrm{r}=1$ & $\mathrm{r}=2$ & 21.750 & 27.584 \\
\hline$r \leq 2$ & $r \geq 3$ & 24.654 & 29.797 & $\mathrm{r}=2$ & $r=3$ & 13.297 & 21.132 \\
\hline $\mathrm{r} \leq 4$ & $r \geq 5$ & 3.33 & 3.842 & $\mathrm{r}=4$ & $\mathrm{r}=5$ & 3.330 & 3.842 \\
\hline \multicolumn{8}{|c|}{ Exchange rate volatility and coffee export } \\
\hline \multicolumn{4}{|c|}{ Trace test } & \multicolumn{4}{|c|}{ Maximum eigen value test } \\
\hline Ho & $\mathrm{H} 1$ & Statistic & $5 \% \mathrm{CV}$ & Ho & H1 & Statistic & $5 \% \mathrm{CV}$ \\
\hline$r \leq 3$ & $r \geq 4$ & 9.963 & 15.495 & $r=3$ & $\mathrm{r}=4$ & 6.923 & 14.265 \\
\hline $\mathrm{r} \leq 4$ & $r \geq 5$ & 3.040 & 3.842 & $r=4$ & $\mathrm{r}=5$ & 3.04 & 3.842 \\
\hline \multicolumn{8}{|c|}{ Exchange rate volatility and cotton export } \\
\hline \multicolumn{4}{|c|}{ Trace test } & \multicolumn{4}{|c|}{ Maximum eigen value test } \\
\hline Но & H1 & Statistic & $5 \% \mathrm{CV}$ & Но & H1 & Statistic & $5 \% \mathrm{CV}$ \\
\hline$r=0$ & $r \geq 1$ & $100.073 * *$ & 69.819 & $\mathrm{r}=0$ & $\mathrm{r}=1$ & $50.623 * *$ & 33.877 \\
\hline $\mathrm{r} \leq 1$ & $r \geq 2$ & 49.450 & 47.856 & $\mathrm{r}=1$ & $\mathrm{r}=2$ & 22.877 & 27.584 \\
\hline $\mathrm{r} \leq 2$ & $r \geq 3$ & 26.573 & 29.797 & $\mathrm{r}=2$ & $r=3$ & 13.488 & 21.132 \\
\hline
\end{tabular}

Note: ** denotes rejection of the hypothesis at the $5 \%$ level based on MacKinnon-Haug-Michelis (1999) critical values. Both the trace and max eigen value indicate 1 co-integration equation at $5 \%$ level of significance for each of the export products.

Source: author's computation from E-views (2016).

Table 2: Johansen co-integration test results (to be continued). 


\begin{tabular}{|c|c|c|c|c|c|c|c|}
\hline \multicolumn{8}{|c|}{ Exchange rate volatility and rubber export } \\
\hline \multicolumn{4}{|c|}{ Trace test } & \multicolumn{4}{|c|}{ Maximum eigen value test } \\
\hline Ho & H1 & Statistic & $5 \% \mathrm{CV}$ & Ho & H1 & Statistic & $5 \% \mathrm{CV}$ \\
\hline$r \leq 1$ & $r \geq 2$ & 36.216 & 47.856 & $r=1$ & $r=2$ & 14.996 & 27.584 \\
\hline$r \leq 2$ & $r \geq 3$ & 21.220 & 29.797 & $r=2$ & $r=3$ & 9.593 & 21.132 \\
\hline $\mathrm{r} \leq 4$ & $r \geq 5$ & 4.311 & 3.842 & $r=4$ & $\mathrm{r}=5$ & 4.311 & 3.842 \\
\hline
\end{tabular}

Note: ** denotes rejection of the hypothesis at the $5 \%$ level based on MacKinnon-Haug-Michelis (1999) critical values. Both the trace and max eigen value indicate 1 co-integration equation at $5 \%$ level of significance for each of the export products.

Source: author's computation from E-views (2016).

Table 2: Johansen co-integration test results (continuation).

value of 69.819 at 5\% level of significance. The long run co-integration test in table 2 shows that .1 co-integration equation exists between real exchange rate volatility and cocoa exports while controlling for other potential determinants of the latter. Based on this, the null hypothesis of no co-integration between real exchange rate volatility and cocoa export is rejected.

The co-integration test results for real exchange rate volatility and coffee export are presented in the second panel of table 2 . The results indicate that co-integration exists among the variables. This is indicated by the Max-Eigen statistics of 42.037 which is greater than the critical value of 33.877 as well as the trace statistics of 84.324 which is greater than the critical value of 69.819 at $5 \%$ level of significance. The long run co-integration test in table 2 shows that 1 co-integration equation exists between real exchange rate volatility and coffee exports while controlling for other potential determinants of the latter. Therefore, the null hypothesis of no co-integration between real exchange rate volatility and coffee export is rejected.

Also, the co-integration test results for real exchange rate volatility and cotton export are presented in the third panel of table 2. The results indicate that co-integration exists among the variables. This is indicated by the Max-Eigen statistics of 50.623 which is greater than the critical value of 33.877 as well as the trace statistics of 100.073 which is greater than the critical value of 69.819 at $5 \%$ level of significance. The long run co-integration test in table 2 shows that 1 co-integration equation exist between real exchange rate volatility and cotton exports while controlling for other potential determinants of the latter. Based on this, the null hypothesis of no co-integration between real exchange rate volatility and cotton export is rejected.

Lastly, co-integration test results for real exchange rate volatility and rubber export are presented in the fourth panel of table 2 . The result shows that co-integration exists among the variables. This is indicated by the Max-Eigen statistics of 33.953 which is greater than the critical value of 33.877 as well as the trace statistics of 70.169 which is greater than the critical value of 69.819 at $5 \%$ level of significance. The long run co-integration test in table 2 indicates that 1 co-integration equation exists between real exchange rate volatility and rubber exports while controlling for other potential determinants of the latter.

The existence of co-integration among real exchange rate volatility and the various agricultural products exports and their fundamentals necessitated the specification of vector error correction model (VECM). Empirical estimates for the long run relationship between real exchange rate volatility and agricultural products are presented in table 3 . It is noted that due to normalization process in the cointegrating vector with the export variables coefficients set to 1 , the sign on the coefficients for the rest of the variables have been reserved.

The long run estimates presented in the first column of table 3 indicates that, a $1 \%$ increase in trade openness (TOP) will result to $0.808 \%$ increase in cocoa export (EXCOC), this implies that more trade openness led to increase in cocoa export in Nigeria. A $1 \%$ increase in interest rate (INR) decreases cocoa export by $0.655 \%$. Furthermore, a $1 \%$ increase in inflation (INF) result to $0.038 \%$ decrease in cocoa export. Lastly, a $1 \%$ increase in real exchange rate volatility (RERV) leads to $1.357 \%$ decrease in cocoa export. It is evident from the result that all the variables (TOP, INR, INF and RERV) have significant long run effect on cocoa export. TOP, INR and RERV were significant at $1 \%$ while INF was significant at $10 \%$.

The second column of table 3 shows the estimates of the long run effect of real exchange rate volatility on coffee export (EXCOF). The result shows that, 


\begin{tabular}{lcccc}
\hline & EXCOC & EXCOF & EXCOT & EXRUB \\
\hline TOP(-1) & $0.808^{* * *}$ & -0.227 & $15.943^{* * *}$ & $2.793^{* * *}$ \\
& $(0.132)$ & 0.833 & $(3.978)$ & $(0.469)$ \\
& {$[6.133]$} & {$[0.273]$} & {$[4.008]$} & {$[5.957]$} \\
INR(-1) & $-0.655^{* * *}$ & $1.708^{* *}$ & $-9.752^{* * *}$ & $-1.510^{* * *}$ \\
& $(0.118)$ & 0.771 & $(3.560)$ & $(0.430)$ \\
& {$[-5.533]$} & {$[-2.217]$} & {$[-2.740]$} & {$[-3.511]$} \\
INF(-1) & $-0.038^{*}$ & 0.06 & 0.846 & $-0.276^{* * *}$ \\
& $(0.021)$ & 0.126 & $(0.592)$ & $(0.071)$ \\
& {$[-1.832]$} & {$[0.476]$} & {$[1.431]$} & {$[-3.898]$} \\
RERV(-1) & $-1.357^{* * *}$ & $-9.289 * * *$ & -5.763 & $-8.798^{* * *}$ \\
& $(0.477)$ & -3.155 & $(13.647)$ & $(1.804)$ \\
& {$[-2.848]$} & {$[-2.944]$} & {$[-0.422]$} & {$[-4.876]$} \\
C & -13.377 & -10.356 & -17.945 & -12.648 \\
\hline
\end{tabular}

Note: *,* and $* * *$ indicate significance at $10 \%, 5 \%$ and $1 \%$ level, respectively. Standard errors are in parenthesis while $\mathrm{t}$-values are in brackets. Lag selections were done based on the AIC and SIC.

Source: author's computation from E-views (2016).

Table 3: Long run effect of real exchange rate volatility on agricultural products export.

a $1 \%$ increase in trade openness result in $0.227 \%$ decrease in coffee export (EXCOF). However, a $1 \%$ increase in interest rate results to $1.708 \%$ increase in coffee export (EXCOF). Furthermore, a $1 \%$ increase in inflation rate increases coffee export (EXCOF) by $0.060 \%$. A $1 \%$ increase in real exchange rate volatility result to $9.289 \%$ decrease in coffee export (EXCOF). The result further revealed that among the variables of interest, it is only INR and RERV that had significant long run effect on coffee export. INR and RERV were significant at $5 \%$ and $1 \%$ respectively.

Empirical estimates for the long run effect of real exchange rate volatility on cotton export are reported in third column of table 3 . This result indicates that, a $1 \%$ increase in trade openness result to $15.943 \%$ increase in cotton export (EXCOT). Also, a $1 \%$ increase in interest rate decreases cotton export (EXCOT) by $9.752 \%$. Furthermore, a $1 \%$ increase in inflation results to $0.846 \%$ increase in cotton export. A $1 \%$ increase in real exchange rate volatility leads to $5.763 \%$ decrease in cotton export. It is however observed that only INR and RERV had significant long run effect on cotton export with the former being significant $5 \%$ while the latter is significant at $1 \%$.

The long run estimate of the effect of real exchange rate volatility on rubber export (EXRUB) is presented the fourth column of table 3 . The result indicates that, a $1 \%$ increase in trade openness leads to increase in rubber export by $2.793 \%$. Also, a $1 \%$ increase in interest rate results in $1.510 \%$ decrease in rubber export. Similarly, a $1 \%$ increase in inflation rate results in $0.275 \%$ decrease in rubber export. Also, a $1 \%$ increase in real exchange rate volatility result in $8.797 \%$ decrease in rubber export. All the variables (TOP, INR, INF and RERV) have significant long run effect on rubber export at $1 \%$ level.

Short run effect of real exchange rate volatility on agricultural products export

The short run estimates of the vector error correction model (VECM) are presented in Table 4 for each agricultural product exports. In the short run, the error correction term (ECT) for the EXCOC equation is rightly signed $(-0.507)$ as revealed in column 2 . This signifies that there is a high speed of adjustment towards equilibrium. The coefficient of Determinants $\left(R^{2}\right)$ of 0.520 indicates that $52 \%$ of the variation in cocoa export is attributed to the variables included in the VECM while the remaining $48 \%$ are due to other variables that are not included in the model.

From column 2, it is evident that a $1 \%$ increase in trade openness in the past year resulted to $0.630 \%$ decrease in cocoa export in the current year. Also, a $1 \%$ increase in trade openness in the past two years resulted to $0.283 \%$ increase in cocoa export in the current year. The result further revealed that the short run effect of trade openness over the previous years on cocoa export in the current year is negative in the first year and positive in the second year but not significant in both years. This implies that while cocoa exports responds negatively to trade policy shock in the first year, it response to the same trade policy in the second year was positive. 
Also, a $1 \%$ increase in interest rate in the past one year resulted to $0.010 \%$ increase in cocoa export in the current year. That is to say, as the interest rate increases the volume of cocoa commodity exports also increases. A $1 \%$ increase in interest rate in the past two years resulted to $0.298 \%$ decrease in cocoa export in the current year. The result shows that the previous year short run effects of interest rate on the cocoa export are not significant. This result contradicts the empirical findings by Onyenweaku and Madu (1991) on the supply response of Nigeria's cocoa that posted evidence of negative output even in the face of rising producer price. Similarly, a $1 \%$ increase in inflation rate during the first year resulted to $0.237 \%$ decrease in cocoa export in the current year. That is to say, increase in inflation rate in the first year discourages cocoa export in the current year. Also, a 1\% increase in inflation rate in the past two years leads to $0.012 \%$ increase in cocoa export in the current year. This implies that the previous two year's values of inflation rate enhanced cocoa export supply.

Furthermore, a $1 \%$ increase in real exchange rate volatility in the past one year leads to $0.420 \%$ decrease in cocoa export in the current year. During the second year, a $1 \%$ increase in real exchange rate volatility leads to $0.293 \%$ decrease in cocoa export. The result also revealed that the short run effect of real exchange rate volatility in the past years is jointly negative but not significant. These negative coefficients may likely mean that the previous year's exchange rate was not favourable to encourage cocoa exports supply in the current year. This result consolidates the findings of Adubi and Okumadewa (1999), they argued that the more volatile the exchange rate is, the higher the risk associated with the variable. It is also noted from the result that a $1 \%$ increase in cocoa export in the first one year resulted to $0.253 \%$ decrease in current cocoa export in the current year. Also, a $1 \%$ increase in cocoa export in the past two years resulted to $0.155 \%$ decrease in current cocoa export in the current year. The result further revealed that the short run effects of cocoa export in the previous year on current cocoa exports are both negative and not significant.

Results in column 3 shows that in the short run the error correction term (ECT) for the EXCOF equation is rightly signed (-0.911) and significant at $1 \%$. This signifies that there is a high speed of adjustment towards equilibrium whereby about $91 \%$ of the disequilibria is removed in one period. The coefficient of Determinants $\left(R^{2}\right)$ of 0.506 indicates that the variables included in the EXCOC equation contributes to about $51 \%$ of its variation. The result revealed that in the short run, a $1 \%$ increase in trade openness (TOP $(-1)$ ) a year ago resulted to $1.106 \%$ decrease in coffee export (EXCOF) in the current year. From the result it is also evident that the short run effect of the explanatory variable (TOP) over the previous year is negative but not significant.

Also a $1 \%$ increase in interest rate (INR (-1)) in the previous year's amount to $1.273 \%$ decrease in coffee export (EXCOF) in the current year. This result revealed that the previous year's effect of interest rate on the coffee export seems to be negative in the short run but not significant.

In the case of inflation, a $1 \%$ increase in the first year results to $1.449 \%$ decrease in coffee export in the current year. The result shows that the short run effect of previous year's inflation on coffee export is negative and significant at $10 \%$. From the result also, a $1 \%$ increase in the real exchange rate volatility in the first year resulted to $7.171 \%$ decrease in coffee export in the current year. This result revealed that the short run relationship is negative in the first year but not significant. Lastly, a $1 \%$ increase in coffee export in the first year resulted to $0.571 \%$ increase in the coffee export in the current year and the effect is significant at $1 \%$.

In the short run, the error correction term (ECT) which measures the speed of adjustment towards equilibrium is negative in the cotton export (EXCOT) equation in column 4 , significant at $1 \%$ level and less than one, which is appropriate. The result justifies the use of ECM specification of the model. One important finding is the statistical significance of the ECM suggesting that cotton export adjust to correct disequilibrium between itself and its determinants. The coefficient of the ECM revealed that the speed with which cotton export adjust to real exchange rate volatility is $97 \%$ in the short run. The result also shows that the coefficient of determinant $\left(\mathrm{R}^{\wedge} 2\right)$ of cotton export is 0.718 , thus the included variables explain $71.80 \%$ of the variations in the cotton export.

The short run result shows that a $1 \%$ increase in trade openness in the first year leads to $18.989 \%$ decrease in cotton export in the current year. And in the second year, a 1\% increase in trade openness resulted to 3.330 decrease in cotton export in the current year. This study disagree with the findings of (Agbeyegbe et al. 2004) who noted that trade openness as a policy help in removal of non-tariffs obstacles to imports, the rationalization and lowering of tariffs, establishment of market 


\begin{tabular}{|c|c|c|c|c|}
\hline Error Correction: & EXCOC & EXCOF & EXCOT & EXRUB \\
\hline \multirow[t]{3}{*}{ CointEq1 } & -0.507 & $-0.911 * * *$ & $-0.967 * * *$ & $-0.221 * *$ \\
\hline & $(0.319)$ & 0.163 & $(0.146)$ & $(0.097)$ \\
\hline & {$[-1.590]$} & {$[-5.599]$} & {$[-6.622]$} & {$[-2.281]$} \\
\hline \multirow[t]{3}{*}{ TOP(-1) } & -0.63 & -1.106 & $-18.989 * * *$ & -0.537 \\
\hline & $(0.409)$ & 1.106 & (4.903) & $(0.399)$ \\
\hline & {$[-1.538]$} & {$[-1.000]$} & {$[-3.873]$} & {$[-1.344]$} \\
\hline \multirow[t]{3}{*}{ TOP(-2) } & 0.283 & - & -3.33 & - \\
\hline & $(0.366)$ & - & $(4.812)$ & - \\
\hline & {$[0.775]$} & - & {$[-0.692]$} & - \\
\hline \multirow[t]{3}{*}{$\operatorname{INR}(-1)$} & 0.010 & -1.273 & 0.751 & -0.535 \\
\hline & $(0.298)$ & 1.124 & $(4.530)$ & $(0.345)$ \\
\hline & {$[0.035]$} & {$[-1.133]$} & {$[0.166]$} & {$[-1.550]$} \\
\hline \multirow[t]{3}{*}{$\operatorname{INR}(-2)$} & -0.298 & - & $-8.322 * *$ & - \\
\hline & $(0.280)$ & - & $(4.203)$ & - \\
\hline & {$[-1.002]$} & - & {$[-1.980]$} & - \\
\hline \multirow[t]{3}{*}{$\operatorname{INF}(-1)$} & -0.237 & $-1.449^{*}$ & 3.248 & 0.018 \\
\hline & $(0.417)$ & 0.769 & $(5.756)$ & $(0.361)$ \\
\hline & {$[-0.568]$} & [ -1.883$]$ & {$[0.564]$} & [ 0.049] \\
\hline \multirow[t]{3}{*}{$\operatorname{INF}(-2)$} & 0.012 & - & 7.028 & - \\
\hline & $(0.382)$ & - & $(5.877)$ & - \\
\hline & {$[0.031]$} & - & [ 1.196] & - \\
\hline \multirow[t]{3}{*}{ RERV(-1) } & -0.42 & -7.171 & -27.201 & -0.136 \\
\hline & $(1.371)$ & 5.364 & (19.596) & (1.478) \\
\hline & {$[-0.306]$} & {$[-1.338]$} & {$[-1.388]$} & [ - 0.092$]$ \\
\hline \multirow[t]{3}{*}{ RERV(-2) } & -0.292 & - & -9.541 & - \\
\hline & $(1.274)$ & - & (19.839) & - \\
\hline & {$[-0.229]$} & - & {$[-0.481]$} & - \\
\hline \multirow[t]{3}{*}{$\operatorname{EXCOC}(-1)$} & -0.253 & $0.571 * * *$ & $0.292 * *$ & 0.156 \\
\hline & $(0.296)$ & 0.159 & $(0.121)$ & $(0.187)$ \\
\hline & {$[-0.853]$} & [ 3.597] & [ 2.422] & {$[0.832]$} \\
\hline \multirow[t]{3}{*}{$\operatorname{EXCOC}(-2)$} & -0.155 & - & $0.359 * * *$ & - \\
\hline & $(0.208)$ & - & $(0.116)$ & - \\
\hline & {$[-0.745]$} & - & [ 3.107] & - \\
\hline \multirow[t]{3}{*}{$\mathrm{C}$} & 0.048 & -0.05 & -1.026 & 0.026 \\
\hline & $(0.087)$ & -0.268 & (1.136) & $(0.078)$ \\
\hline & {$[0.556]$} & {$[-0.188]$} & {$[-0.903]$} & [ 0.337$]$ \\
\hline R-squared & 0.520 & 0.506 & 0.718 & 0.159 \\
\hline Adj. R-squared & 0.332 & 0.418 & 0.607 & 0.011 \\
\hline F-statistic & 2.760 & 5.798 & 6.479 & 1.071 \\
\hline
\end{tabular}

Note: $*, * *$ and $* * *$ indicate significance at $10 \%, 5 \%$ and $1 \%$ level, respectively. Standard errors are in parenthesis while $t$-values are in brackets. Lag selections were done based on the AIC and SIC.

Source: author's computation from E-views (2016).

Table 4: Short run effect of real exchange rate volatility on agricultural products export.

mechanism as a medium of foreign exchange rate determination and removal of fiscal disincentives and regulatory measures that prevent exports. From the result, the short run effects of trade openness in the previous years are both negative but jointly significant at $1 \%$ level. This implies that policy of trade openness did not favour export supply of the commodity (cotton) in the past years. Also, a $1 \%$ increase in interest rate in the past one year resulted to $0.751 \%$ increase in cotton export in the current year. In the second year, a $1 \%$ increase in interest rate resulted to $8.322 \%$ 
decrease in cotton export in the current year. The short run effect of interest rate on cotton export is positive but not significant in the first year and negative but significant at 5\% level in the second year.The result further revealed that a $1 \%$ increase in inflation rate in the past one year resulted to $3.248 \%$ increase in cotton export in the current year. Also, a $1 \%$ increase in inflation rate results to $7.028 \%$ increase in cotton export in the current year. From the result, it is evident that the short run effects of inflation rate over the previous years on cotton export in the current year is jointly positive but not significant.

More so, a1\% increase in real exchange rate volatility in the past one year resulted to $27.201 \%$ decrease in cotton export in the current year. In the second year, a $1 \%$ increase in real exchange rate volatility resulted to $9.541 \%$ decrease in cotton export in the current year. The result further shows a negative and as well as not significant short run effects of real exchange rate volatility on cotton export in the first and second year. This implies that as the exchange rate increases, most cotton farmers in Nigeria stop productivity and this reduced the volume of cotton exports drastically. This result supports the findings of Oluremi (1998) that both real exchange rate misalignment and volatility adversely discourage growth in the non-oil sector, in which the agriculture is the dominant sector. Based on his empirical findings he posits that Nigerian producers are less risk averse and would react to any adverse exchange rate movement by reducing production.

Lastly, a $1 \%$ increase in cotton export in the past one year resulted to $0.292 \%$ increase in cotton export in the current. Also, a 1\% increase in cotton export in the past two years resulted to $0.359 \%$ increase in cotton export in the current year. From the result, it is evident that the short run effect of cotton export in the past years are both positive and jointly significant at 5\% level in the past one year and at $1 \%$ level in the past two years respectively on cotton export in the current year. Column 5 indicates that, in the short run, the error correction term (ECT) in the rubber export (EXRUB) equation is negatively signed (-0.221) and significant at $5 \%$. This implies that the speed of adjustment towards equilibrium is relatively slow as only about $22 \%$ of the disequilibria is removed in one period. The coefficient of determinant $\left(R^{2}\right)$ of 0.159 indicates that only $16 \%$ of variations rubber export is jointly explained by the variables included in the VECM. The coefficient of determinant $\left(R^{2}\right)$ value for rubber export seem relatively low, but as opined by Gujarati (2008:222), a low $R^{2}$ value should not be of serious concern but accentuation should be given to the significance of the regressors estimates as well as the model in general.

From column 5, a $1 \%$ increase in trade openness in the past one year resulted to $0.537 \%$ decrease in rubber export in the current year. Also, a $1 \%$ increase in interest rate in the past one year resulted to $0.535 \%$ decrease in rubber export in the current year. This negative coefficient of trade openness and interest rate shows that both variables during the study period did not favour rubber export supply. A $1 \%$ increase in inflation rate in the past one year also resulted to $0.018 \%$ increase in rubber export in the current year. Similarly, a $1 \%$ increase in real exchange rate volatility in the past one year amount to $0.136 \%$ increase in rubber export in the current year. Also, a $1 \%$ increase in rubber export in the past one year resulted to $0.156 \%$ increase in rubber export in the current year.

The result further revealed that among the explanatory variables, real exchange rate volatility, trade openness and interest rate shows a negative short run effect on the dependent variable (rubber export) in the current year. Inflation rate and rubber export in the past one year on the hand shows a positive short run effect. Although none of these explanatory variable is said to be significant. This result is in line with Nwachukwu (2014) who believed that low short run and long run elasticities of supply imply that the producers of rubber in Nigeria did not make significant short run and long run production adjustment in response to changes in prices. The result also consolidates the findings of Mesike et al. (2010) who also had low elasticities in his supply response study of rubber farmers.

\section{Granger causality test result}

The Granger Causality result in table 5 between real exchange rate volatility (RERV) and cocoa export (EXCOC) shows a bidirectional causality that run from real exchange rate volatility (RERV) to cocoa export (EXCOC) and vice versa. These findings imply that the past values of RERV can be used to forecast or predict the current values of EXCOC and the past values of EXCOC can be used to predict the current values of RERV. In the same vein, unidirectional causality was equally observed in the relationship between real exchange rate volatility (RERV) and rubber export (EXRUB) i.e. the latter Granger causes the former but not vice versa. In this case the past values of EXRUB can be used to predict the current values of RERV. The null hypothesis of no Granger causality cannot be rejected in the case of cotton 
export (EXCOT) and coffee export (EXCOF). These results confirm the lack of significant short run effect of exchange rate volatility on these agricultural product exports.

\begin{tabular}{lccc}
\hline Null hypothesis & Chi-square & P-value & Decision \\
\hline $\begin{array}{l}\text { RERV does not Granger } \\
\text { cause EXCOC }\end{array}$ & 10.322 & 0.001 & Reject \\
$\begin{array}{l}\text { EXCOC does not } \\
\text { Granger cause RERV }\end{array}$ & 5.924 & 0.014 & Reject \\
$\begin{array}{l}\text { RERV does not Granger } \\
\text { cause EXCOF }\end{array}$ & 0.065 & 0.798 & Accept \\
$\begin{array}{l}\text { EXCOF does not } \\
\text { Granger cause RERV }\end{array}$ & 0.118 & 0.732 & Accept \\
$\begin{array}{l}\text { RERV does not Granger } \\
\text { cause EXCOT }\end{array}$ & 0.308 & 0.579 & Accept \\
$\begin{array}{l}\text { EXCOT does not } \\
\text { Granger cause RERV }\end{array}$ & 0.022 & 0.882 & Accept \\
$\begin{array}{l}\text { RERV does not Granger } \\
\text { cause EXRUB }\end{array}$ & 0.778 & 0.378 & Reject \\
$\begin{array}{l}\text { EXRUB does not } \\
\text { Granger cause RERV }\end{array}$ & 3.266 & 0.071 & Accept \\
\hline
\end{tabular}

Source: author's computation from E-views (2016)

Table 5: Granger causality test result.

Overall the findings in this study are largely consistent with De Vita and Abbott (2004) for the UK sectoral level analysis who found insignificant short run effect of exchange rate volatility but significant long run effect on sectoral (manufacturing, food and beverage and basic materials) exports. They are also consistent with Wang and Barrett (2007) for Taiwan, Cho et al. (2002) G-10 countries and Kandilov (2008) on developing and developed countries who all found significant negative effect of exchange rate volatility on aggregate agricultural exports. However our findings constrasts results by Awokuse and Yuan, 2006 on U.S. poultry exports who found a positive relationship between exchange rate volatility and poultry exports.

Corresponding authors:

Friday Otse Alegwu

Department of Agricultural Economics, University of Agriculture Makurdi, P.M.B 2373, Nigeria E-mail: otsealegwu@gmail.com

\section{References}

[1] Abiodun, E. O. and Salau, S. A. (2010) "Agricultural Response to Prices and Exchange Rate In Nigeria: Application of Co-integration and Vector Error Correction Model (VECM)", Journal of Agricultural Sciences, Vol. 1, No. 2, pp. 73-81. ISSN 0976-6898. DOI 10.1080/09766898.2010.11884656.

[2] Adubi, A. A. and Okunmadewa, F. (1999) "Price exchange rate volatility and Nigeria's agricultural trade flows: A dynamic analysis", African Economic Research Consortium (AERC), Research paper 87, Nairobi March 1999. ISSN 1824-2979.

\section{Conclusion} exchange rate volatility on agricultural products export in Nigeria. Results indicate that one co-integration exists between exchange rate volatility and each of the agricultural products export while controlling for other variables implying that stable long run equilibrium exists among the variables of interest. Exchange rate volatility has negative long run effect on all agricultural exports studied with the effect being strongest for coffee followed by rubber. Results based on the VECM framework shows evidence of negative short run effect of real exchange rate volatility on agricultural products export. The Granger causality test results revealed that there is bidirectional causality between cocoa export and exchange rate volatility. Overall, we found that exchange rate volatility has no significant effect on agricultural products export while it has a long run effect on it. This finding has important implication. The lack of significant effect of exchange rate volatility on agricultural products exports may be due to adjustment or switching costs involved in selling into foreign markets. It could also be that exporters can easily and less expensively insure or hedge against short term risks through forward looking market trading. However, the significant effect in the long term could be seen as inability of the exporters to hedge against long term risks since these may be more costly to do relative to the short term risks. The study recommends measures that will promote greater exchange rate stability and improve terms of trade conditions. Also measures that would enable agricultural products exporters to insure against both short and long term risks effectively would be helpful.
The aim of this study is to examine the effect of real 
[3] Agbeyegbe, T., Stotsky, J. and Woldemariam, A. (2004) "Trade liberalization, Exchange Rate Change and Tax Revenue in sub-Sahara Africa", Hunter College Department of Economics Working Papers No. 4/173. ISBN/ISSN 9781451858983/1018-5941. DOI 10.1016/j.asieco.2005.09.003.

[4] Amoro, G. and Shen, Y. (2013) "The Determinants of Agricultural Export: Cocoa and Rubber on Cote d'Ivoire", International Journal of Economics and Finance, Vol. 5, No. 1, pp. 228 - 233. E-ISSN 1916-9728, ISSN 1916-971X. DOI 10.5539/ijef.v5n1p228.

[5] Awokuse, T. O. and Yuan, Y. (2006) "The impact of Exchange Rate Volatility on U.S. Poultry Exports”, Agribusiness, Vol. 22, No. 2, pp. 233-245. E-ISSN 1520-6297. DOI 10.1002/agr.20082.

[6] Cho, G., Sheldon, I. and McCorriston, S. (2002) "Exchange Rate Uncertainty and Agricultural Trade", American Journal of Agricultural Economics, Vol. 84, No. 4, pp. 931-942. E-ISSN 1467-8276, ISSN 0002-9092. DOI 10.1111/1467-8276.00044.

[7] De Vita, G. and Abbott, A. (2004) "The Impact of Exchange Rate Volatility on UK exports to EU Countries", Scottish Journal of Political Economy, Vol. 51, No.1, pp. 62-81. E-ISSN 1467-9485. DOI 10.1111/j.0036-9292.2004.05101004.x.

[8] Foragasi, J. (2011) "The Effect of Exchange Rate Volatility upon Foreign Trade of Hungarian Agricultural Products", Research Institute of Agriculture Economics - Hungarian Academy of Sciences; Studies in Agricultural Economics, No. 113, pp. 85-96. ISBN 14182106.

[9] Gujarati, D. N. (2008) "Basic Econometrics 4 $4^{\text {th }}$ Edition", New York: McGraw-Hill, pp. 222. ISBN 0072427922.

[10] Ivanov, V. and Kilian, L. (2005) "A Practitioner's Guide to Lag Order Selection for VAR Impulse Response Analysis", Studies in Nonlinear Dynamics \& Econometrics, Vol. 9, No. 1, pp. 1-34. ISSN 1558-3708. E-ISSN 1558-3708. DOI 10.2202/1558-3708.1219.

[11] Kandilov, I. T. (2008) "The effects of exchange rate volatility on agricultural trade", American Journal of Agricultural Economics, Vol. 90, No. 2, pp. 1028-1043. E-ISSN 1467-8276. DOI 10.1111/j.1467-8276.2008.01167.x.

[12] Mackinnon, J. G. (1991) "Critical Values for Cointegration Tests", Chapter 13, In R. F. Engle and C. W. J. Granger (Eds.) "Long-run Economic Relationships: Readings in Cointegration", pp. 267-276. Oxfords: Oxford University Press.

[13] Mackinnon, J. G., Haug, A. A. and Michelis, L. (1999) "Numerical distribution functions of Likelihood ratio tests for Cointegration", Journal of Applied Econometrics, Vol. 14, No. 5, pp. 563-577. E-ISSN 1099-1255. DOI 10.1002/(SICI)1099-1255(199909/10)14:5<563::AIDJAE530>3.0.CO;2-R.

[14] Mesike, C. S., Okoh, R. N. and Inoni, O. E. (2010) "Supply Response of Rubber Farmers in Nigeria: An Application of Vector Error Correction Model", Journal of American Science, Vol. 6, No. 9, pp. 52-56. ISSN 1545-1003. DOI 10.3923/aj.2010.146.150.

[15] Nwachukwu, N. J. (2014) "Dynamics of Agricultural Exports in Sub-Sahara Africa: An Empirical Study of Rubber and Cocoa from Nigeria", International Journal of Food and Agricultural Economics, Vol. 2, No. 3, pp. 91-104. ISSN 2147-8988.

[16] Oluremi, O. (1998) "Real Exchange Rate Movements and Export Growth: Nigeria, 1960- 1990", Paper 82, Nairobi: African Economic Research Consortum. [Online]. Available: http://opendocs. ids.ac.uk/handle/123456789/2224 [Accessed: 20 Feb 2018].

[17] Onyenweaku, C. E. and Madu, E. N. (1991) "Perennial Crop supply Response: The Case of Nigeria Cocoa", Paper Presented at the $1^{\text {st }}$ International Conference on Tree Crops, MANR, Imo State.

[18] Orden, D. (2002) "Exchange Rate Effects on Agricultural Trade", Journal of Agricultural and AppliedEconomics, Vol. 34, No.2, pp. 303-312. ISSN 1074-0708, E-ISSN 2056-7405. DOI 10.1017/S1074070800009056.

[19] Sasore, G. M. (2004) "Nigeria's Export Trade of Agricultural Commodities: Quality Control and Standards", A Paper presented at Nigeria National Crop Outlook Conference, Durbar Hotel, Kano. $26-27^{\text {th }}$ May, 2004. 
[20] Wang, K. and Barrett, C. (2007) "Effect of Exchange Rate Volatility on Export Volumes", Journal of Agricultural and Resource Economics, Vol. 32, No. 2, pp. 225-255. ISSN 1068-5502.

[21] Yusuf, S. A. and Falusi, A. O. (1999) "Incidence analysis of the effects of liberalized trade and exchange rate policies on cocoa in Nigeria: An ECM Approach", Journal of Rural Economic Development, Vol.13, No. 2, pp. 3-14. [Online]. Available: http;//www.jstor.Org/stable/40987362 [Accessed: 4 March 2018]. ISSN 1813-2235, E-ISSN 1814-960X. 